\title{
Smokers having Activating EGFR Mutant Non-Small Cell Lung Cancer Might Benefit from EGFR-TKI Treatment - Single-Center Experience
}

\author{
(1) Özlem ERCELEP, 1 Tugba AKIN TELLì, ${ }^{2}$ (D) Özkan ALAN, ${ }^{2}$ (D) Rahib HASANOV, ${ }^{2}$ \\ Dda TANRIKULU ŞIMŞEK, ${ }^{2}$ (D) Nalan AKGÜL BABACAN,' (D) Serap KAYA, ${ }^{1}$ (D) Handan KAYA, ${ }^{3}$ \\ (D) Faysal DANE, ${ }^{2}$ (1) Perran Fulden YUMUK ${ }^{2}$ \\ 'Department of Medical Oncology, Marmara University Pendik Training and Research Hospital, Istanbul-Turkey \\ 2Department of Medical Oncology, Marmara University, Faculty of Medicine, Istanbul-Turkey \\ ${ }^{3}$ Department of Pathology, Marmara University, Faculty of Medicine, Istanbul-Turkey
}

\begin{abstract}
OBJECTIVE
This study aims to evaluate the predictive impacts of cigarette smoking on treatment outcomes of EGFR tyrosine kinase inhibitors (TKIs) in Non-Small Cell Lung Cancer (NSCLC) patients with activating EGFR mutations.
\end{abstract}

\section{METHODS}

We retrospectively evaluated the data of 46 patients with metastatic NSCLC (adenocarcinoma) and EGFR mutation (exon 19 deletion, exon 21 mutation, and exon 18 activating mutation) treated with EGFR-TKI between 2012 and 2017.

\section{RESULTS}

Median age was 61 (range 30-80), and 56.5\% (26/46) was female. Median follow-up was 39 months. The rate of smoking was $41.3 \%$ (19/46). The EGFR mutations were present in the patients, exon 19 deletion in 29 patients (64\%), exon 21 mutation in 13 patients $(28 \%)$ and exon 18 activating mutations in four patients (8\%). Progression-free survival (PFS) was 21 months in smokers, whereas it was 25 months in non-smokers $(\mathrm{p}=0.330)$. Median PFS was 21 months for patients using EGFR TKI in the first-line (35 patients), and 13 months in the second-line setting (11 patients).

\section{CONCLUSION}

There were no statistically significant PFS differences between the smoker and non-smoker groups. Smokers should be tested for EGFR mutations, as some patients may benefit from EGFR TKI treatment for longer than reported in the literature.

Keywords: Epidermal growth factor receptor; smoking; tyrosine kinase inhibitors.

Copyright $\odot$ 2020, Turkish Society for Radiation Oncology

\section{Introduction}

Lung cancer is among the most common cancers worldwide. Although smoking is proven to be one of the major risk factors for lung cancer, approximately
$25 \%$ of lung cancer cases worldwide are not attributable to smoking.[1-3]

EGFR mutations are more prevalent in certain subpopulations of patients with NSCLC, such as women, patients in East Asia, patients with adenocarcinoma
Received: April 08, 2020

Accepted: April 09, 2020

Online: June 18, 2020

Accessible online at:

www.onkder.org

OPEN ACCESS This work is licensed under a Creative Commons

Attribution-NonCommercial 4.0 International License.
Dr. Özlem ERCELEP

Marmara Üniversitesi,

Pendik Eğitim ve Araştırma Hastanesi,

Tıbbi Onkoloji Kliniği,

İstanbul-Turkey

E-mail: ozlembalvan@yahoo.com 
histologic types, and non-smokers. [4-5] The frequency of activating EGFR mutations, including exon 19 inframe deletions and exon 21 L858R substitution, has been reported to be $40 \%$ to $60 \%$ in non-smoking patients compared to $10 \%$ to $20 \%$ in tobacco-associated patients for NSCLC.[6-9]

Treating NSCLC patients having activating EGFR mutations with tyrosine kinase inhibitor (TKI) significantly prolongs progression-free survival compared to standard chemotherapy and is more tolerable.[10-14] Various genetic alterations have been reported as resistance mechanisms to EGFR-TKI treatment, including T790M mutation, MET amplification and KRAS mutation,[15-17] but mechanisms and clinical factors that react differently to EGFR-TKI in EGFR mutated NSCLC are still largely unknown.[17]

Preclinical studies in recent years have shown that cigarette smoking abnormally activates the EGFR pathway and that active EGFR cells are resistant to smoking and EGFR-TKIs.[18,19] In addition, there were more somatic mutation incidence and genetic complexity in NSCLC patients with smoking history than non-smoking patients.[20]

Few studies directly focus on the relationship between EGFR-TKI's response and cigarette smoking history in NSCLC EGFR-mutant patients. In this study, we aimed to evaluate the effects of smoking cessation on anti-EGFR treatment in the Turkish patient population.

\section{Materials and Methods}

Between 2012-2017, EGFR activating mutations were present in 46 of 344 patients with stage 4 non-squamous NSCLC (13\%). Forty-one of the patients were diagnosed in the metastatic stage and five in the nonmetastatic stage. We retrospectively evaluated the data of 46 patients with metastatic NSCLC (adenocarcinoma) having activating EGFR mutations (exon 19 deletion in 29 patients, exon 21 mutation in 13 patients, exon 18 activating mutation in four patients) and treated with EGFR TKI (erlotinib) (first line 35 patients, second line 11 patients). We grouped the patients as smokers $(n=16)$ and non-smokers $(n=30)$ and compared the clinicopathologic features (ECOG performance status, mutation status, stage of diagnosis, EGFR TKI first line or second line usage, weight loss, gender, CEA and LDH level) of both groups. In descriptive statistics of data, we used mean, standard deviation, median lowest value, median highest value, frequency and rates. In the analysis of survival, we used
Kaplan-Meier and Cox-regression analysis and in the analysis of qualitative data, we used the Chi-Square test.

\section{Results}

Median age was 61 (30-80), and 56.5\% (26/46) was female. Median follow-up was 39 months. The rate of smoking was $41.3 \%$ (19/46). Fifteen of the 19 smokers had over 30 pack-year smoking history. Female gender (20/27) was higher in non-smoker patients and male sex $(13 / 19)$ was higher in smokers $(p=0.04)$. In all patients, PFS time was 21 months, where PFS was 21 months in smokers and 25 months in non-smokers $(\mathrm{p}=0.330)$ (Fig. 1). Overall survival was 26 months in the smoker group and 47 months in the non-smoker group ( $\mathrm{p}=0.475)$ (Table 1 ).

We compared the clinicopathologic features (age, gender, 1st or 2nd line usage, LDH or CEA levels, ECOG PS, smoking, weight loss, mutation status) of smokers and non-smokers, and there was no significant difference. LDH elevation was found in $63 \%$ and CEA elevation was found in $50 \%$ of the patients. Sixty four percent $(\mathrm{n}=29)$ of the patients had exon 19 deletion, $28 \%(\mathrm{n}=13)$ had exon 21 mutation, and $8 \%(\mathrm{n}=4)$ had activating exon 18 mutations (Table 2).

Median PFS was 21 months (2-35) for patients using Erlotinib in the first-line (35 patients) and 13 months (5$30)$ in the second-line setting (11 patients). There were

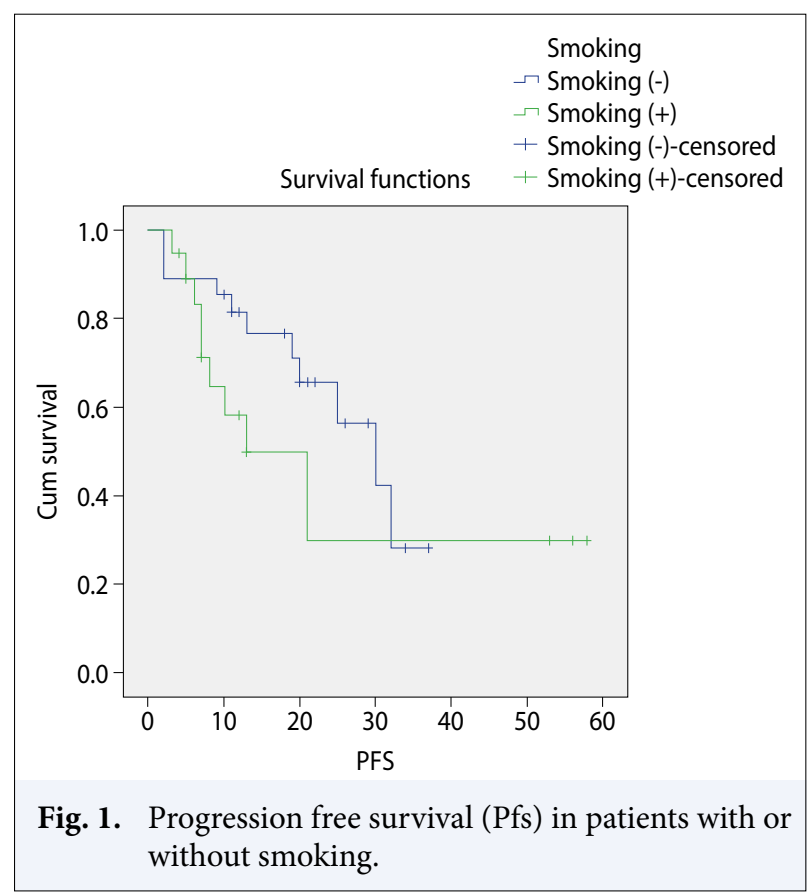


Table 1 Survival data (Kaplan-Meier)

\begin{tabular}{|c|c|c|c|c|c|c|c|}
\hline & Min. & - & Max. & Median & $\mathbf{n}$ & $\%$ & $\mathbf{p}$ \\
\hline Follow-up duration (Months) & 4 & - & 65 & 39 & & 3.8 & \\
\hline \multicolumn{8}{|l|}{ Status } \\
\hline Died & & & & & 21 & 45.3 & \\
\hline Alive & & & & & 25 & 54.3 & \\
\hline Progression-free survival (PFS) & 2 & - & 58 & 21 & & 370.0 & \\
\hline \multicolumn{8}{|l|}{ Progression } \\
\hline No & & & & & 23 & 50.0 & \\
\hline Yes & & & & & 23 & 50.0 & \\
\hline \multicolumn{8}{|l|}{ Overall survival time } \\
\hline Smoking (+) & & & & 26 & & & 0.408 \\
\hline Smoking (-) & & & & 47 & & & \\
\hline \multicolumn{8}{|l|}{ PFS time } \\
\hline Smoking (+) & & & & 25 & & & 0.33 \\
\hline Smoking (-) & & & & 21 & & & \\
\hline
\end{tabular}

Table 2 Clinicopathologic data (Chi-Square)

\begin{tabular}{|c|c|c|c|c|c|c|c|}
\hline & \multicolumn{2}{|c|}{ Smoking (+) } & \multicolumn{2}{|c|}{ Smoking (-) } & \multicolumn{2}{|c|}{ All } & \\
\hline & $n=19$ & $41.3 \%$ & $n=27$ & $58.7 \%$ & $n=46$ & $100 \%$ & \\
\hline \multicolumn{8}{|l|}{ Age } \\
\hline$\leq 65$ & 12 & 63.2 & 13 & 48.1 & 25 & 54 & 0.314 \\
\hline$>65$ & 7 & 36.8 & 14 & 51.9 & 21 & 46 & \\
\hline \multicolumn{8}{|c|}{ EGFR-TKI $1^{\text {st }}$ or $2^{\text {nd }}$ line usage } \\
\hline $1^{\text {st }}$ line & 12 & 63.2 & 23 & 85.2 & 35 & 76 & 0.085 \\
\hline $2^{\text {nd }}$ line & 7 & 36.8 & 4 & 14.8 & 11 & 24 & \\
\hline \multicolumn{8}{|c|}{ Stage of diagnosis stage } \\
\hline Metastatic & 18 & 94.7 & 23 & 85.2 & 41 & 89 & 0.305 \\
\hline Non-metastatic & 1 & 5.3 & 4 & 14.8 & 5 & 11 & \\
\hline \multicolumn{8}{|l|}{ Mutation status } \\
\hline Exon 19 deletion & 13 & 68.4 & 16 & 59.3 & 29 & 64 & 0.135 \\
\hline Exon 21 mutation & 5 & 26.3 & 8 & 21.6 & 13 & 28 & \\
\hline Exon 18 mutation & 1 & 5.3 & 3 & 11.1 & 4 & 8 & \\
\hline \multicolumn{8}{|l|}{ ECOG PS } \\
\hline$<1$ & 18 & 100 & 23 & 85.2 & 41 & 89 & 0.189 \\
\hline$\geq 2$ & 1 & 0 & 4 & 14.8 & 5 & 11 & \\
\hline \multicolumn{8}{|l|}{ Gender } \\
\hline Female & 6 & 31.6 & 20 & 74.1 & 26 & 56.5 & 0.004 \\
\hline Male & 13 & 68.4 & 7 & 25.9 & 20 & 46.5 & \\
\hline \multicolumn{8}{|l|}{ Weight loss } \\
\hline Yes & 3 & 17.6 & 2 & 13.3 & 5 & 15.6 & 0.598 \\
\hline No & 14 & 82.4 & 13 & 86.7 & 27 & 84.4 & \\
\hline \multicolumn{8}{|l|}{ CEA } \\
\hline Normal & 6 & 50 & 8 & 50 & 14 & 50 & 0.647 \\
\hline High & 6 & 50 & 8 & 50 & 14 & 50 & \\
\hline \multicolumn{8}{|l|}{$\mathrm{LDH}$} \\
\hline Normal & 5 & 29.4 & 7 & 36.8 & 12 & 36.8 & 0.637 \\
\hline High & 12 & 70.6 & 12 & 63.2 & 24 & 63.2 & \\
\hline
\end{tabular}

EGFR-TKI: Epidermal growth factor receptor-tyrosine kinase inhibitor; ECOG-PS: Eastern cooperative oncology group performance status; CEA: Carcinoembryonic antigen; LDH: Lactate dehydrogenase 


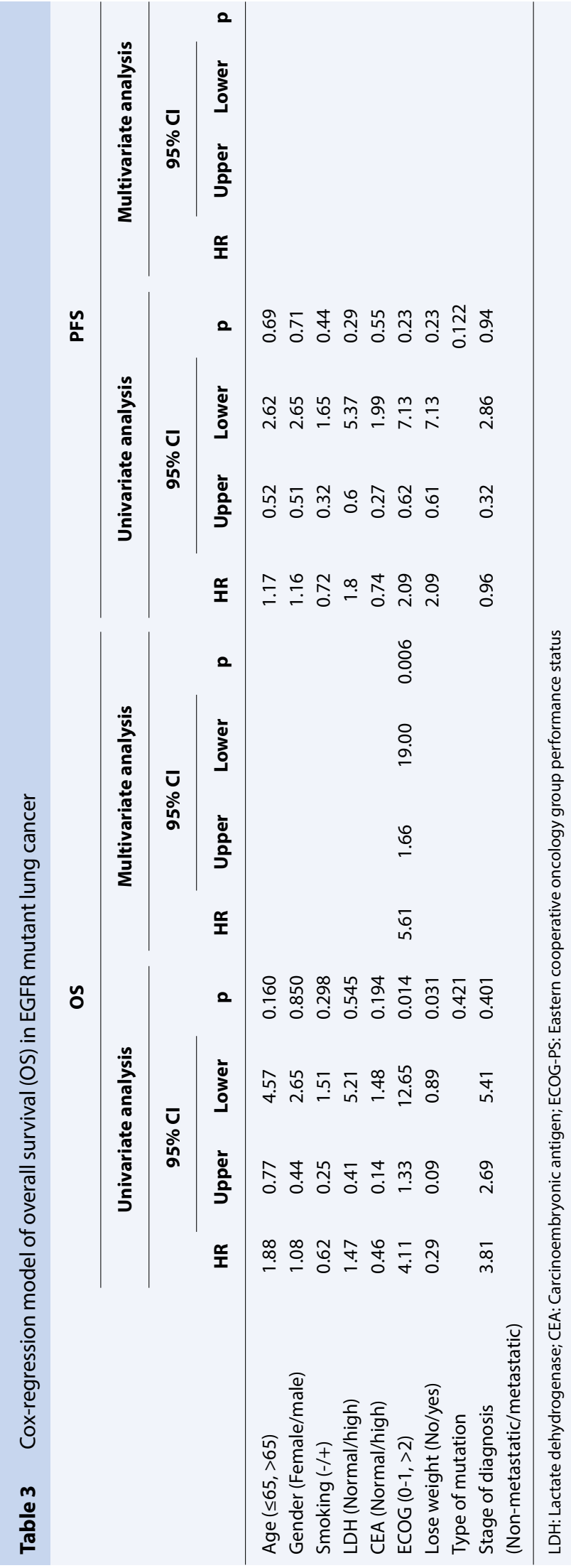

27 patients with PFS 12 months or more and 19 patients with less than 12 months. No statistically significant difference was found for PFS when clinicopathologic features (age, gender, $1^{\text {st }}$ or $2^{\text {nd }}$ line usage, LDH or CEA levels, ECOG PS, smoking, weight loss, mutation status) of these patients were compared (Table 3 ).

Median overall survival time (mOS) for metastatic disease was 39 months (range 4-65). The negative effects of ECOG-PS and weight loss on OS were shown by univariate analysis and the negative effects of ECOG-PS in multivariate analysis (Table 3).

Skin toxicity was observed in 18 patients (43\%), which resulted in treatment interruption, and the dose was reduced in six patients (14\%) due to side effects.

\section{Discussion}

NSCLC in never-smokers differs from NSCLC in smokers in many respects. EGFR mutations appear to be more common in never-smokers than in smokers.[21] Mutations in KRAS are more common in smokers than in never smokers.[22-24] Evidence suggests that these differences in molecular markers may have important implications for treatment choice.[23,24] There is also evidence that no smokers are independently more likely to survive than smokers, regardless of treatment. [25-27] Activating mutation in EGFR is the most important marker that predicts response to EGFR-TKIs in NSCLC.[28-30] The association between smoking history and efficacy of EGFR-TKIs therapy remains unclear. Few studies directly focus on the relationship between EGFR-TKI's efficacy and smoking history in NSCLC EGFR-mutant patients. A retrospective study showed that over 30 pack-years of cigarette smoking was an independent negative predictive factor of EGFRTKI treatment outcome in lung adenocarcinoma patients with activating EGFR mutations.[31]

In a meta-analysis of Zhang et al. in 2015, for advanced NSCLC patients with EGFR mutations, non-smoking is associated with longer PFS than ever smoking after EGFR-TKIs treatment. However, there was no difference in objective response rates (ORR) and disease control rate (DCR). Smoking-related lung cancer is linked to multiple carcinogenic mechanisms. EGFR mutation may be one of the carcinogenic pathways of NSCLC in smokers, but not a single activated signaling pathway. EGFR-TKI may be effective for patients with EGFR mutation at the onset of treatment but cannot block other carcinogenic pathways induced by cigarette smoking, which may be due to that ORR and DCR are not different, although there are short PFSs in smokers.[32] 
A meta-analysis conducted by Mitchell et al. concluded that smoking and its effect on the EGFR-TKI response were still not determined because no data were available on smoking history and relationship to treatment response.[33] In our study, the frequency of patients who had a cigarette smoking history was $34.8 \%$, and this was comparable to the results of the previous studies.[31,34,35]

There were no statistically significant PFS and OS differences between the smoker and non-smoker groups in our study. PFS was 21 months in smokers whereas it was 25 months in non-smokers. Overall survival was 26 months in the smoker group and 47 months in the non-smoker group ( $\mathrm{p}=0.475)$. In our study, the overall median PFS time was 21 months, whereas median PFS is 21 months in patients using erlotinib in the first-line and 13 months in the second-line setting. Our PFS time results are much longer than the literature.

Our study had some limitations. This study was performed retrospectively with a limited sample. In addition, smoking history was only collected at the first diagnosis and smoking status during treatment was not followed up.

\section{Conclusion}

Smokers should be tested for EGFR mutations, as some patients may benefit from EGFR-TKI treatment for longer than reported in the literature. EGFR mutation status should also be considered in smokers. Smoking is known to be associated with poor prognosis in lung cancer, but these patients may benefit from EGFR-TKI treatments.

Peer-review: Externally peer-reviewed.

Conflict of Interest: None declared.

Ethics Committee Approval: The authors declare that this research was conducted in accordance with the ethical principles of the Declaration of Helsinki.

Financial Support: Financial support was not received.

Authorship contributions: Concept - Ö.E., T.A.T.; Design - Ö.E.; Supervision - Ö.E.; Funding - Ö.E.; Materials - Ö.E.; Data collection and/or processing - Ö.A., E.T.Ş., R.H.; Data analysis and/or interpretation - Ö.E.; Literature search N.B., Ö.E.; Writing - S.K., Ö.E.; Critical review - P.F.Y., F.D.

\section{References}

1. Wynder EL, Graham EA. Landmark article May 27, 1950: Tobacco Smoking as a possible etiologic factor in bronchiogenic carcinoma. A study of six hundred and eighty-four proved cases. By Ernest L. Wynder and Evarts A. Graham. JAMA 1985;253(20):2986-94.

2. Parkin DM, Bray F, Ferlay J, Pisani P. Global cancer statistics, 2002. CA Cancer J Clin 2005;55:74-108.

3. Sun S, Schiller JH, Gazdar AF. Lung cancer in never smokers--a different disease. Nat Rev Cancer.2007;7(10):778-90.

4. Rosell R, Moran T, Queralt C, Porta R, Cardenal F, Camps $\mathrm{C}$, et al. Screening for epidermal growth factor receptor mutations in lung cancer. N Engl J Med 2009;361(10):958-67.

5. Zhang YL, Yuan JQ, Wang KF, Fu XH, Han XR, Threapleton $\mathrm{D}$, et al. The prevalence of EGFR mutation in patients with non-small cell lung cancer: a systematic review and meta-analysis. Oncotarget 2016;7(48):78985-93.

6. Shigematsu H, Lin L, Takahashi T, Nomura M, Suzuki $\mathrm{M}$, Wistuba II, et al. Clinical and biological features associated with epidermal growth factor receptor gene mutations in lung cancers. J Natl Cancer Inst 2005;97:339-46.

7. Ahn MJ, Park BB, Ahn JS, Kim SW, Kim HT, Lee JS, et al. Are there any ethnic differences in molecular predictors of erlotinib efficacy in advanced non-small cell lung cancer? Clin Cancer Res 2008;14(12):38606.

8. Tomizawa $\mathrm{Y}$, Iijima $\mathrm{H}$, Sunaga $\mathrm{N}$, Sato K, Takise A, Otani Y, et al. Clinicopathologic significance of the mutations of the epidermal growth factor receptor gene in patients with nonesmall cell lung cancer. Clin Cancer Res 2005;11:6816-22.

9. Hsieh RK, Lim KH, Kuo HT, Tzen CY, Huang MJ. Female sex and bronchioloalveolar pathologic subtype predict EGFR mutations in non-small cell lung cancer. Chest 2005;128(1):317-21.

10.Zhou C, Wu YL, Chen G, Feng J, Liu XQ, Wang C, et al. Erlotinib versus chemotherapy as first-line treatment for patients with advanced EGFR mutation-positive non-small-cell lung cancer (OPTIMAL, CTONG-0802): a multicentre, open-label, randomised, phase 3 study. Lancet Oncol 2011;12:735.

11. Rosell R, Carcereny E, Gervais R, Vergnenegre A, Massuti B, Felip E, et al. Erlotinib versus standard chemotherapy as first-line treatment for European patients with advanced EGFR mutation-positive non-small-cell lung cancer (EURTAC): a multicentre, open-label, randomised phase 3 trial. Lancet Oncol 2012;13:239.

12. Wu YL, Zhou C, Liam CK, Wu G, Liu X, Zhong Z, et al. First-line erlotinib versus gemcitabine/cisplatin in patients with advanced EGFR mutation-positive nonsmall-cell lung cancer: analyses from the phase III, randomized, open-label, ENSURE study. Ann Oncol 2015;26:1883. 
13. Fukuoka M, Wu YL, Thongprasert S, Sunpaweravong P, Leong SS, Sriuranpong VF, et al. Biomarker analyses and final overall survival results from a phase III, randomized, open-label, first-line study of gefitinib versus carboplatin/paclitaxel in clinically selected patients with advanced non-small-cell lung cancer in Asia (IPASS). J Clin Oncol 2011;29:2866.

14. Mok TS, Wu YL, Thongprasert S, Yang CH, Chu DT, Saijo N, et al. Gefitinib or carboplatin-paclitaxel in pulmonary adenocarcinoma. N Engl J Med 2009;361(10):947-57.

15. Engelman JA, Zejnullahu K, Mitsudomi T, Song Y, Hyland C, Park JO, et al. MET amplification leads to gefitinib resistance in lung cancer by activating ERBB3signaling. Science 2007;316:1039-43.

16. Kobayashi S, Boggon TJ, Dayaram T, Jänne PA, Kocher $\mathrm{O}$, Meyerson M, Jet al. EGFR mutation and resistance of non-small-cell lung cancer to gefitinib. $\mathrm{N}$ Engl J Med. 2005 Feb 24;352(8):786-92.

17. Wheeler DL, Dunn EF, Harari PM. Understanding resistance to EGFR inhibitors-impact on future treatment strategies. Nat Rev Clin Oncol 2010;7(9):493507.

18. Filosto S, Becker CR, Goldkorn T. Cigarette smoke induces aberrant EGF receptor activation that mediates lung cancer development and resistance to tyrosine kinase inhibitors. Mol Cancer Ther 2012;11(4):795-804.

19. Khan EM, Lanir R, Danielson AR, Goldkorn T. Epidermal growth factor receptor exposed to cigarette smoke is aberrantly activated and undergoes perinuclear trafficking. FASEB J 2008;22(3):910-7.

20. Govindan R, Ding L, Griffith M, Subramanian J, Dees ND, Kanchi KL, et al.Genomic landscape of non-small cell lung cancer in smokers and never-smokers. Cell 2012;150:1121-34.

21.Pao W, Miller V, Zakowski M, Doherty J, Politi K, Sarkaria I, et al. EGF receptor gene mutations are common in lung cancers from "never smokers" and are associated with sensitivity of tumors to gefitinib and erlotinib. Proc Natl Acad Sci U S A 2004;101:13306-11.

22. Sun S, Schiller JH, Gazdar AF. Lung cancer in never smokers-a different disease. Nat Rev Cancer 2007;7:778-90.

23. Rudin CM1, Avila-Tang E, Harris CC, Herman JG, Hirsch FR, Pao W, et al. Lung cancer in never smokers: molecular profiles and therapeutic implications. Clin Cancer Res 2009;15:5646-61.

24. Eberhard DA1, Johnson BE, Amler LC, Goddard AD, Heldens SL, Herbst RS, et al. Mutations in the epidermal growth factor receptor and in KRAS are predictive and prognostic indicators in patients with nonsmall-cell lung cancer treated with chemotherapy alone and in combination with erlotinib. J Clin Oncol 2005;23:5900-9.
25. Itaya T, Yamaoto N, Ando M, Ebisawa M, Nakamura $\mathrm{Y}$, Murakami $\mathrm{H}$, et al. Influence of histological type, smoking history and chemotherapy on survival after first-line therapy in patients with advanced non-small cell lung cancer. Cancer Sci 2007;98(2):226-30.

26. Janjigian YY, McDonnell K, Kris MG, Shen R, Sima CS, Bach PB, et al. Pack-years of cigarette smoking as a prognostic factor in patients with stage IIIB/IV nonsmall cell lung cancer. Cancer 2010;116:670-5.

27. Kawaguchi T, Takada M, Kubo A, Matsumura A, Fukai $\mathrm{S}$, Tamura A, et al. Performance status and smoking status are independent favorable prognostic factors for survival in non-small cell lung cancer: a comprehensive analysis of 26,957 patients with NSCLC. J Thorac Oncol 2010;5(5):620-30.

28. Chang A, Parikh P, Thongprasert S, Tan EH, Perng $\mathrm{RP}$, Ganzon D, et al. Gefitinib (IRESSA) in patients of Asian origin with refractory advanced non-small cell lung cancer: subset analysis from the ISEL study. J Thorac Oncol 2006;1(8):847-55.

29. Maemondo M, Inoue A, Kobayashi K, Sugawara S, Oizumi S, Isobe $\mathrm{H}$, et al. Gefitinib or chemotherapy for non-small-cell lung cancer with mutated EGFR. N Engl J Med. 2010;362(25):2380-8.

30. Lynch TJ, Bell DW, Sordella R, Gurubhagavatula S, Okimoto RA, Brannigan BW, et al. Activating mutations in the epidermal growth factor receptor underlying responsiveness of non-small-cell lung cancer to gefitinib. N Engl J Med 2004;350(21):2129-39.

31. Kim MH, Kim HR, Cho BC, Bae MK, Kim EY, Lee $\mathrm{CY}$, et al. Impact of cigarette smoking on response to epidermal growth factor receptor (EGFR)etyrosine kinase inhibitors in lung adenocarcinoma with activating EGFR mutations. Lung Cancer 2014;84:196-202.

32. Zhang Y, Kang S, Fang W, Hong S, Liang W, Yan Y, et al. Impact of smoking status on EGFR-TKI efficacy for advanced non-small-cell lung cancer in EGFR mutants: a meta-analysis. Clin Lung Cancer 2015;16(2):144-51.e1.

33. Mitchell P, Mok T, Barraclough H, Strizek A, Lew R, van Kooten M. Smokinghistory as a predictive factor of treatment response in advanced non-small-celllung cancer: a systematic review. Clinical Lung Cancer 2012;13:239-51.

34. Rosell R, Moran T, Queralt C, Porta R, Cardenal F, Camps $\mathrm{C}$, et al. Screeningfor epidermal growth factor receptor mutations in lung cancer. New EnglandJournal of Medicine 2009;361:958-67.

35. D’Angelo SP, Pietanza MC, Johnson ML, Riely GJ, Miller VA, Sima CS, et al. Incidence of EGFR exon 19 deletions and L858R in tumor specimens from men and cigarette smokers with lung adenocarcinomas. J Clin Oncol 2011;29(15):2066-70. 